\title{
Basal temperature and thermal sum in phenological phases of nectarine and peach cultivars
}

\author{
Adilson Pacheco de Souza ${ }^{(1)}$, Sarita Leonel(2) e Andréa Carvalho da Silva(1) \\ (1)Universidade Federal de Mato Grosso, Instituto de Ciências Agrárias e Ambientais, Campus Sinop, Avenida Brasília, no 1.200, \\ Setor Industrial, CEP 78557-267 Sinop, MT. E-mail: adilsonpacheco@ufmt.br, acarvalho@ufmt.br (2)Universidade Estadual Paulista, \\ Departamento de Produção Vegetal, Faculdade de Ciências Agronômicas, Fazenda Experimental Lageado, CEP $18603-970$ Botucatu, SP. \\ E-mail: sarinel@fca.unesp.br
}

\begin{abstract}
The objective of this work was to evaluate basal temperature, thermal sum at different phenological stages, phenological phase duration, yield and seasonality of one nectarine and 14 peach cultivars, between 2006 and 2009. The considered phenological phases were: pruning-sprouting; sprouting-flowering, from swollen bud to open flower; flowering-fruiting, from petal fall to medium-sized fruit; and ripening. Minimum basal temperatures $(\mathrm{Tb})$ obtained were: pruning-sprouting, $8^{\circ} \mathrm{C}$, irrespective of the cultivars; sproutingflowering, $10^{\circ} \mathrm{C}$, except for 'Cascata $968^{\prime}$, which required $8^{\circ} \mathrm{C} \mathrm{Tb}$; flowering-fruiting, $12^{\circ} \mathrm{C}$, except for 'Oro Azteca', which required $14^{\circ} \mathrm{C} \mathrm{Tb}$; ripening, $14^{\circ} \mathrm{C}$, except for 'Sunblaze', 'Diamante Mejorado' and 'Precocinho' with $12^{\circ} \mathrm{C} \mathrm{Tb}$. For most cultivars, the maximum basal temperatures were $30,34,34$ and $28^{\circ} \mathrm{C}$ for phases pruning-sprouting, sprouting-flowering, flowering-fruiting and ripening, respectively. 'Turmalina', 'Marli' and 'Tropic Beauty' showed average yields of 3,945.0, 3,969.3 and 3,954.0 $\mathrm{kg} \mathrm{ha}^{-1}$, respectively, in 2009, while the nectarine 'Sunblaze' showed around 3,900 kg ha-1 in 2008 and 2009. The cultivars differed for their total cycle and for the accumulated thermal sums which varied, respectively, from 245 days and 1,881.4 degree-days for 'Oro Azteca', to144 days and 1,455.7 degree-days for 'Precocinho'.
\end{abstract}

Index terms: Prunus persica, degree day, thermal unit.

\section{Temperatura basal e soma térmica em fases fenológicas de cultivares de nectarineira e pessegueiro}

\begin{abstract}
Resumo - O objetivo deste trabalho foi avaliar a temperatura basal, a soma térmica acumulada em diferentes fases fenológicas, a duração das fenofases, a produtividade e a sazonalidade do ciclo de uma cultivar de nectarina e de 14 cultivares de pêssego, entre 2006 e 2009. As fases fenológicas consideradas foram: podabrotação; brotação-florescimento, da gema inchada até a flor aberta; florescimento-frutificação, da queda das pétalas até o fruto médio; e maturação. As temperaturas basais mínimas obtidas foram: poda-brotação, $8^{\circ} \mathrm{C}$, independentemente das cultivares avaliadas; brotação-florescimento, $10^{\circ} \mathrm{C}$, com exceção de 'Cascata $968^{\prime}$, que necessitou de $\mathrm{Tb}$ de $8^{\circ} \mathrm{C}$; florescimento-frutificação, $12^{\circ} \mathrm{C}$, exceto 'Oro Azteca', que necessitou de $\mathrm{Tb}$ de $14^{\circ} \mathrm{C}$; maturação, $14^{\circ} \mathrm{C}$, com exceção de 'Sunblaze', 'Diamante Mejorado' e 'Precocinho', com $\mathrm{Tb}$ de $12^{\circ} \mathrm{C}$. Para a maioria das cultivares, as temperaturas basais máximas foram de $30,34,34$ e $28^{\circ} \mathrm{C}$, nas fases poda-brotação, brotação-florescimento, florescimento-frutificação e maturação, respectivamente. 'Turmalina', 'Marli' e 'Tropic Beauty' apresentaram produtividade média de 3.945,0, 3.969,3 e 3.954,0 $\mathrm{kg} \mathrm{ha}^{-1}$, em 2009, respectivamente, enquanto a nectarineira 'Sunblaze' produziu em torno de $3.900 \mathrm{~kg} \mathrm{ha}^{-1} \mathrm{em} 2008$ e 2009. As cultivares diferiram quanto ao ciclo total e quanto às somas térmicas acumuladas que variaram, respectivamente, de 245 dias e $1.881,4$ graus-dia em 'Oro Azteca', a 144 dias e 1.455,7 graus-dia em 'Precocinho'.
\end{abstract}

Termos para indexação: Prunus persica, graus-dia, unidades térmicas.

\section{Introduction}

The advance in peach and nectarine production, in regions of subtropical climate with milder winters, is related to the development of specific cultivars, their behavior in different localities, and the use of special auxiliary techniques for cultivation. In (SP), the harvest begins earlier than in further south states of Brazil. The cultivars developed for SP, with varied fruit ripening cycles, meet market demands from September to February, providing consumers with different types of peaches and nectarines (Barbosa et al., 1997; Ramos \& Leonel, 2008). Except for grape, which represents around $50 \%$ of the total area cultivated with fruit in São Paulo state, peach has gained importance as the main temperate fruit grown in the state, with around two 
million plants, including nectarine, which accounts for $15 \%$ of the peach culture in number of plants (Barbosa et al., 2003; Pedro Júnior et al., 2007).

The expansion of these cultures has been limited by certain major factors, such as insufficient regional tests to indicate which cultivars are adapted to different ecological regions, as well as the lack of phenological characterization for the existent genotypes, and the thermal requirements as to chilling hours for the normal vegetative and flower development.

The development period of peaches is genetically controlled, but varies greatly with seasons and environments (Citadin et al., 2003; Litschmann et al., 2008; Milatovic et al., 2010). The ripening time depends on the flowering time and on the duration of fruit development, which is regulated chiefly by the thermal range from flowering to ripening and by the cultivar response to temperature (Marra et al., 2002; Day et al., 2008).

To obtain a thermal range suitable for a certain plant, the limiting temperatures - minimum and maximum, which indicate null vegetative development - must be considered, showing the minimum energy states suitable for metabolic processes and the maximum levels above which the respiration rate surpasses the photosynthetic rate. The required thermal sum (in degree-days) accumulated in the period, to partially or entirely complete the plant cycle, has been employed according to species needs to describe phenological stages, which allows for crop season planning. Therefore, crop phenological stages can be predicted based on the previous knowledge of daily temperature or mean monthly temperature, the location and the thermal sum required by the plant to achieve its maturity stage, as stated by Arnold (1959), Ometto (1981) and other methods presented by Souza et al. (2011). The thermal sum has been applied to fruit trees as reported by several authors (Marra et al., 2002; Day et al., 2008; Litschmann et al., 2008; Gariglio et al., 2009; Souza et al., 2009). Nevertheless, this application has - as a main requirement - the establishment of limiting temperatures according to the cultivar and to the phenological stage (Sacramento \& Pereira, 2003; Litschmann et al., 2008).

Early estimation of the harvest date may help peach producers to plan the crop management practices efficiently (Day et al., 2008). Brazilian peach producers have traditionally employed categories such as extra-early, early, mid-season, late and extra-late periods to estimate the harvest date of cultivars (Simonetto et al., 2004). This classification is based solely on fruit aspects near maturity, and there was not a quantitative method to link annual variations in the weather to harvest date predictions.

The search for well-adapted materials is one of the first actions to improve orchard yield. Thermal requirement characterization for different peach and nectarine cultivars and selections and the knowledge of the cultivar development cycle are important to define cultural practices, such as dormancy break, thinning, pruning, fertilization, phytosanitation and irrigation in different regions and to identify the cultivars most adapted to a specific region (Pedro Júnior et al., 2007; Souza et al., 2011).

The economic potential of peach culture in Brazil, especially in SP, increased the possibility of diversification of cultivars better adapted to subtropical climates, which could lead to a higher income for producers and higher seasonality of product offer.

The objective of this study was to evaluate the basal temperature, thermal sum at different phenological stages, phenological phase duration, yield and seasonality of one nectarine and 14 peach cultivars.

\section{Materials and Methods}

The experiment was carried out at the Faculdade de Ciências Agronômicas, Universidade Estadual Paulista Júlio de Mesquita Filho (Unesp), Botucatu, SP, Brazil, at $22^{\circ} 51^{\prime} 55^{\prime \prime} \mathrm{S}, 48^{\circ} 27^{\prime} 22^{\prime \prime} \mathrm{W}$ and at $810 \mathrm{~m}$ altitude. According to Köppen's classification, the predominant climate in the study region is Cwa, described as a warm temperate climate (mesothermal), with rainy summers and dry winters. The mean temperature in the coldest month (July) is $17.1^{\circ} \mathrm{C}$ and, in the hottest month (February), $23.3^{\circ} \mathrm{C}$, with $1,314 \mathrm{~mm}$ annual mean rainfall (Clima dos municípios paulistas, 2010). Data on climate, during the four productive cycles, were provided by the meteorological station, of the Departamento de Recursos Naturais, Unesp. The soil is classified as a Nitossolo Vermelho (Santos et al., 2006) corresponding to a Rhodic Kandiudox (Soil Survey Staff, 2010).

The experimental design was completely randomized, with five replicates and 10 plants per plot, two of which were selected for evaluation. In 
July 2006, four-year-old plants were planted at a $6 \mathrm{~m}$ spacing between lines and $4 \mathrm{~m}$ between plants in an upland area. The rootstock 'Okinawa' was used for all canopy cultivars. Evaluations were done between 2006 and 2009.

Cultural phytosanitation practices were performed during the whole experimental period, in order to assure plant development, according to Pereira et al. (2002). Fruit pruning occurred in July 2006, 2007, 2008 and 2009. Plants were allowed to produce flowers and fruit spontaneously, without using plant growth regulators to break dormancy. The need and the intensity of fruit thinning were annually determined by the criterion of the threefold-decrease of fruit quantity in the branches, to allow for better growth of the remaining fruit (Barbosa et al., 1997; Ramos \& Leonel, 2008).

The 14 evaluated peach cultivars were: CP-951 C, CP-9553 CYN, Oro Azteca and Diamante Mejorado, from Mexico (Marodin et al., 2008); Precocinho, Turmalina and Marli, from Empresa Brasileira de Pesquisa Agropecuária (Embrapa); six peach selections, also developed by Embrapa, 'Cascata 953', 'Cascata 797', 'Cascata 587', 'Cascata 848', 'Cascata 968' and 'Conserva 693'; and 'Tropic Beauty', from Florida. The evaluated nectarine cultivar was Sunblaze, which is also from Florida. It must be emphasized that the six peach selections from Embrapa are still being tested by producers and institutions and have not been released for commercial planting yet; thus, there are few data about their development (Raseira \& Nakasu, 2002).

Weekly phenological evaluations were done, and fruit were harvested at the physiological maturity phase, based on the peel coloration, which corresponded to the end of September and mid-December in the four agricultural cycles for all evaluated cultivars.

Based on the phenological scales proposed for peach trees (Gariglio et al., 2009), the following phenological phases and their features were considered to assess the influence of thermal sums: from pruning to sprouting; from sprouting to flowering (from the swollen bud to the opened flower); from flowering to fruiting (from petal fall to the medium-sized fruit "table tennis ball"); and ripening.

Minimum basal temperatures $(\mathrm{Tb})$, in the abovementioned phenophases, were determined by the method of the smallest standard deviation (Arnold, 1959; Souza et al., 2009). The following air temperatures were used, a priori, to calculate the thermal sums at $0,2,4,6,8,10,12,14,16,18$ and $20^{\circ} \mathrm{C}$. The standard deviation (SD) was then determined, in degree-days, for all the four phenophases, and the basal temperature was that corresponding to the lowest standard deviation ( $\mathrm{Sd})$, in days, obtained as follows: $\mathrm{Sd}=\mathrm{SD} /\left(\mathrm{X}_{\mathrm{T}}-\mathrm{Tb}\right)$, in which: $\mathrm{X}_{\mathrm{T}}$ is the mean temperature in the period; $\mathrm{Tb}$ is the preestablished minimum basal temperature.

Similarly to $\mathrm{Tb}$, the maximum basal temperature (TB) was determined when standard deviation values (SD), in days, became constant (Souza et al., 2009). In the present work, two-degree variations in the preestablished temperatures also occurred, ranging from 20 to $40^{\circ} \mathrm{C}$. The thermal requirements of peach and nectarine trees were determined, according to Ometto (1981) and Souza et al. (2011), by equations to estimate degree-days (DD) below:

Case 1: $\mathrm{Tm}>\mathrm{Tb}$; $\mathrm{TB}>\mathrm{TM}, \mathrm{DD}=[(\mathrm{TM}-\mathrm{Tm}) / 2]+(\mathrm{Tm}-\mathrm{Tb})$, Case 2: $\mathrm{Tm} \leq \mathrm{Tb}<\mathrm{TM} ; \mathrm{TB}>\mathrm{TM}, \mathrm{DD}=\left[(\mathrm{TM}-\mathrm{Tb})^{2}\right] / 2(\mathrm{TM}-\mathrm{Tm})$, Case 3: $\mathrm{Tb}>\mathrm{TM} ; \mathrm{TB}>\mathrm{TM}, \mathrm{DD}=0$,

Case 4: $\mathrm{Tb}<\mathrm{Tm} ; \mathrm{TB}<\mathrm{TM}, \mathrm{DD}=\{2[\mathrm{TM}-\mathrm{Tm})(\mathrm{Tm}-$ $\left.\mathrm{Tb})]+(\mathrm{TM}-\mathrm{Tm})^{2}-(\mathrm{TM}-\mathrm{TB})^{2}\right\} / 2(\mathrm{TM}-\mathrm{Tm})$,

Case 5: $\mathrm{Tb}>\mathrm{Tm}$; $\mathrm{TB}<\mathrm{TM}, \mathrm{DD}=0,5\left\{\left[(\mathrm{TM}-\mathrm{Tb})^{2}-\right.\right.$ $\left.\left.(\mathrm{TM}-\mathrm{TB})^{2}\right] /(\mathrm{TM}-\mathrm{Tm})\right\}$, in which: $\mathrm{TM}$ is the maximum daily temperature; $\mathrm{Tm}$ is the minimum daily temperature; $\mathrm{Tb}$ is the minimum basal temperature; $\mathrm{TB}$ is the maximum basal temperature, in ${ }^{\circ} \mathrm{C}$.

Phenophase duration, thermal requirements and yield data were subjected to the analysis of variance by the $\mathrm{F}$ test, and the means were compared by the Scott-Knott test, at $5 \%$ probability.

\section{Results and Discussion}

There was a slight difference in the standard deviation, in days (Figure 1), for the preestablished temperatures, due to the low variability of data on maximum, minimum and mean temperatures in the four productive cycles, except for the sprouting-flowering phase, which occurred between the middle of September and the end of October for most evaluated cultivars, when the monthly mean values of air temperature had the greatest variation.

Irrespective of the cultivar, the basal temperature was $8^{\circ} \mathrm{C}$ in the pruning-sprouting phase. According to Souza et al. (2009), the pruning time does not interfere with the values of the basal temperatures for the same cultivar. For the sprouting-flowering phase, however, $\mathrm{Tb}$ values were $10^{\circ} \mathrm{C}$, except for 'Cascata $968^{\prime}$, which required $8^{\circ} \mathrm{C} \mathrm{Tb}$. In the flowering-fruiting phase, only 'Oro Azteca' required $14^{\circ} \mathrm{C} \mathrm{Tb}$, while, for 
the remaining cultivars, the minimum limiting value was $2{ }^{\circ} \mathrm{C}$ higher than the previous phase. During fruit ripening, basal temperature minimal requirements of $12^{\circ} \mathrm{C}$ were found for nectarine 'Sunblaze', while peach 'Diamante Mejorado' and 'Precocinho' had Tb values of $14^{\circ} \mathrm{C}$ during this period. The $\mathrm{Tb}$ values, found in all phases, differed from those reported by Citadin et al. (2001) for other cultivars in different climatic conditions, in Pelotas, RS, Brazil $\left(\mathrm{Tb}=4.5^{\circ} \mathrm{C}\right)$, as well as by Pérez-Pastor et al. (2004) in Southeastern Spain $\left(\mathrm{Tb}=6.0^{\circ} \mathrm{C}\right)$, by Litschmann et al. (2008) in the Czech Republic $\left(\mathrm{Tb}=7.0^{\circ} \mathrm{C}\right)$, and by Gariglio et al. (2009) in Central-West Argentina $\left(\mathrm{Tb}=4.5^{\circ} \mathrm{C}\right)$.

Early pruning in July allows for sprouts developing in periods of lower temperatures, in the climatic conditions of Botucatu, since the minimum

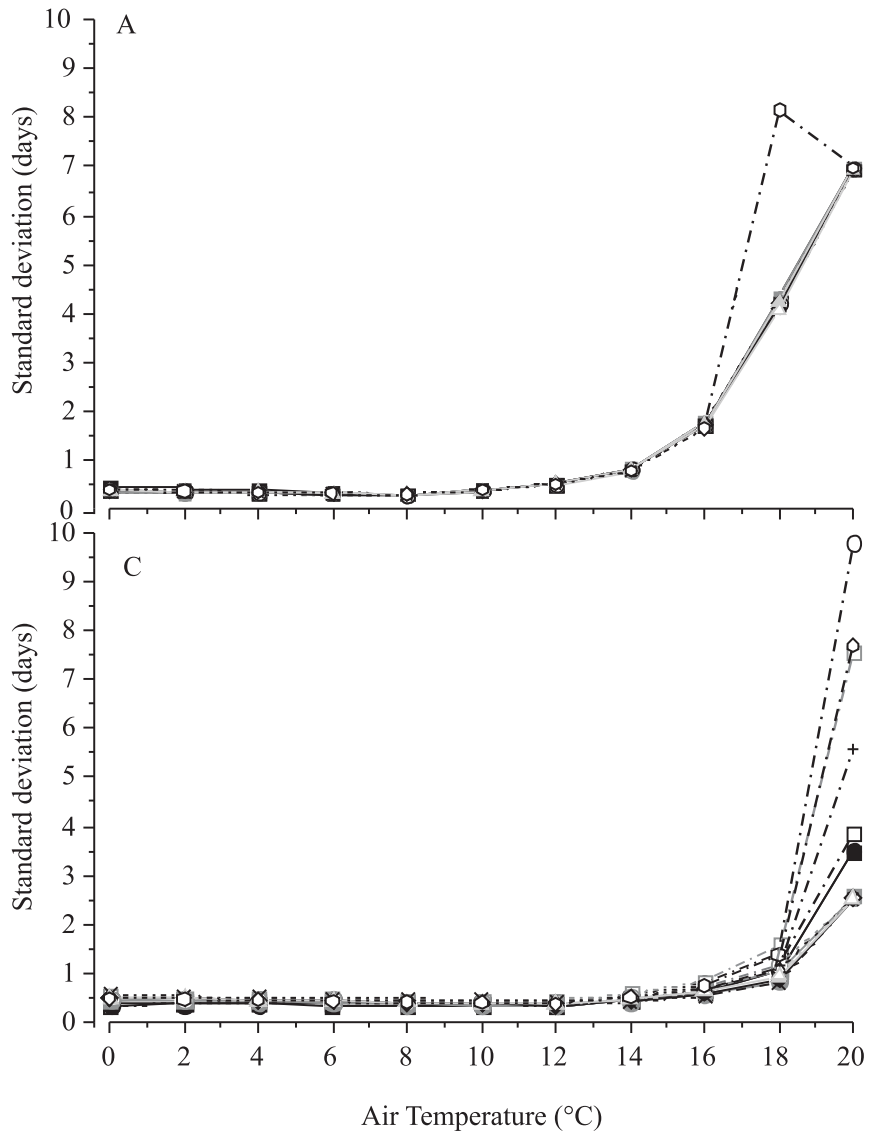

temperatures were less than $8^{\circ} \mathrm{C}$ during $9,7,4$ and 10 days in 2006, 2007, 2008 and 2009, respectively. Thus, the cessation of sprout development is justified by those demands which, when not fulfilled, may lead to injuries to both plants and new sprouts (Gao et al., 2002; Caramori et al., 2008).

According to Raseira \& Nakasu (2002), peach is one of the temperate fruit species which has been most extensively studied and adapted to conditions of warm temperate or subtropical climates. Currently, there are large commercial areas of the species, especially between $30^{\circ} \mathrm{N}$ and $45^{\circ} \mathrm{S}$. These authors have also reported that peach quality is higher in areas with high summer temperatures. Thus, the possibility of expansion of peach culture is mainly due to the thermal requirements of the new cultivars. The maximum basal
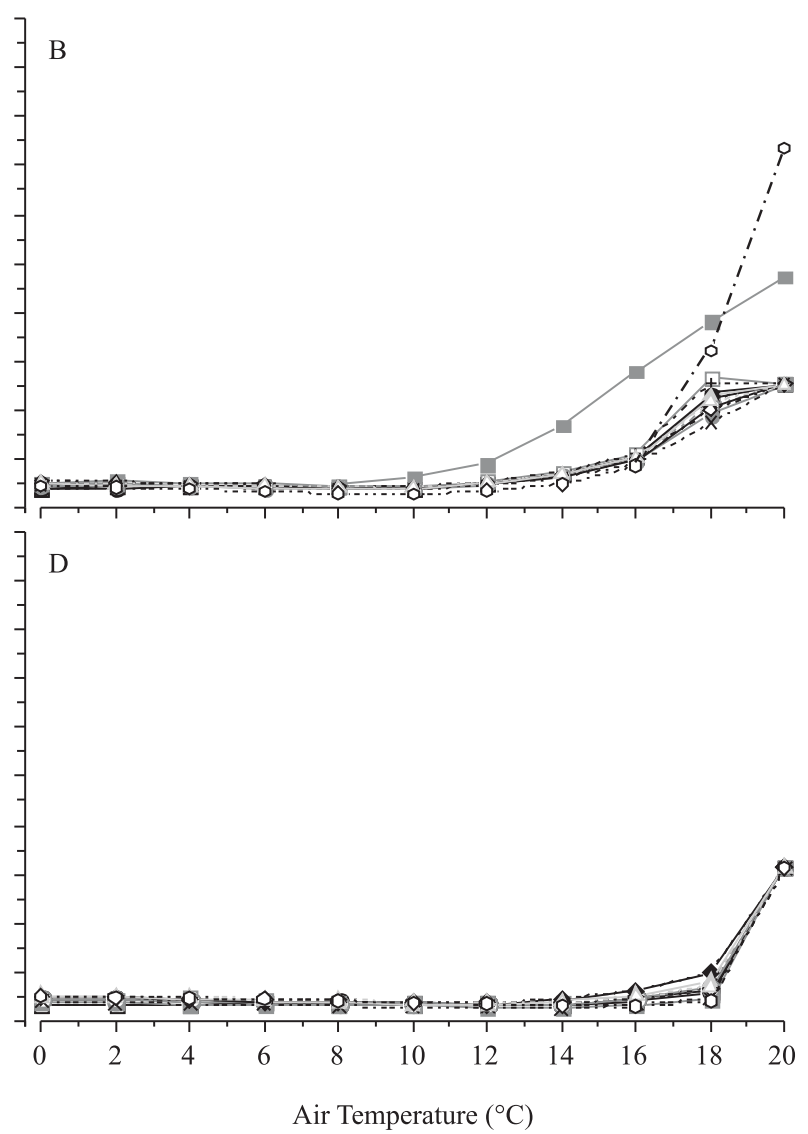

\begin{tabular}{|c|c|c|c|c|}
\hline $\begin{array}{l}\square \text { Cascata } 587 \\
-\boxminus-\cdots \text { Conserva } 693 \\
\cdots \times \cdots \text { Oro Azteca }\end{array}$ & $\begin{array}{l}\cdots-\cdots \text { Cascata } 797 \\
- \text { CP } 951 \text { C } \\
\cdots+\cdots \text { Precocinho }\end{array}$ & $\begin{array}{l}\longrightarrow \text { Cascata } 848 \\
-- \text { CP } 9553 \text { CYN } \\
- \text { Sunblaze }\end{array}$ & $\begin{array}{l}-\bigcirc-\text { Cascata } 953 \\
- \text { Diamante Mejorado } \\
- \text { Tropic Beauty }\end{array}$ & $\begin{array}{l}\longrightarrow \text { Cascata } 968 \\
\cdots \diamond-\text { Marli } \\
\cdots \diamond \cdot \text { Turmalina }\end{array}$ \\
\hline
\end{tabular}

Figure 1. Minimum basal temperatures $(\mathrm{Tb})$ determined by the method of the lowest standard deviation for peach and nectarine cultivars, between pruning-sprouting (A), sprouting-flowering (B), flowering-fruiting (C), and ripening (D), in Botucatu, SP, Brazil, between July 2006 and November 2009. 
temperatures, obtained for 14 peach and one nectarine cultivars, are shown in Figure 2. There was a greater variation in the standard deviation values, in days, interfering with $\mathrm{TB}$ in comparison to $\mathrm{Tb}$ levels in all four evaluated phenophases.

Day et al. (2008) stated that the variation in peach and nectarine harvest date, from year to year, confirms the strong influence of weather on fruit production. The relationships, observed between growing degree-hours and the number of days between full flowering (FFD) and harvest, confirm the importance of air temperature on peach and nectarine fruit development in the month after flowering (Lopez \& Dejong, 2007).
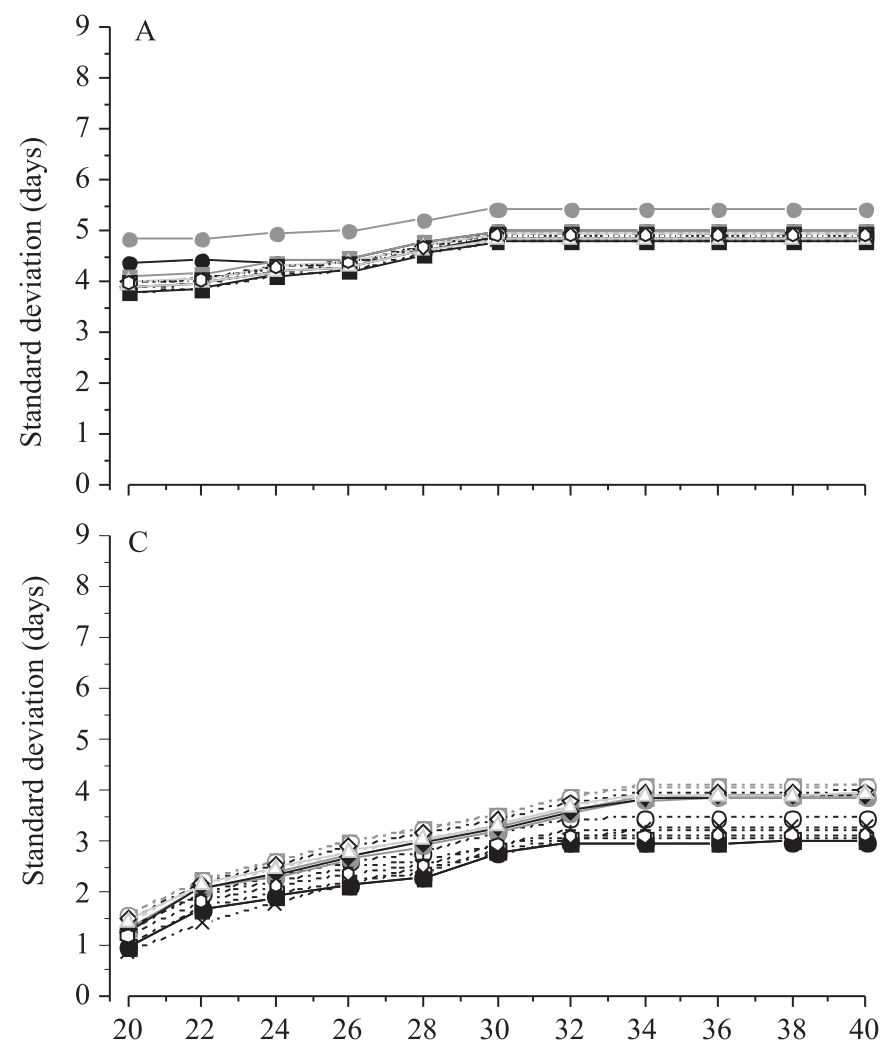

Air Temperature $\left({ }^{\circ} \mathrm{C}\right)$
Peach and nectarine have been cultivated in several climatic and soil conditions, including regions with severe winter (600-1,200 number of chilling hours- $\mathrm{NCH}$ below $7.2^{\circ} \mathrm{C}$ ) in regions almost devoid of hibernal cold (less than $20 \mathrm{NCH}$ below $7.2^{\circ} \mathrm{C}$ ) (Pedro Júnior et al., 2007). The NCH requirement also varies according to the cultivar and the species; the most cultivated varieties in Brazil require from 100 to $500 \mathrm{NCH}$ below $7.2^{\circ} \mathrm{C}$, accumulated from May to September, to complete dormancy (Raseira \& Nakasu, 2002; Caramori et al., 2008; Gariglio et al., 2009).

According to Scarpare Filho et al. (2003), certain rustic peach, plum, pear, persimmon, fig and loquat varieties have been successfully cultivated in warmer regions, with thermal indexes between 40 and
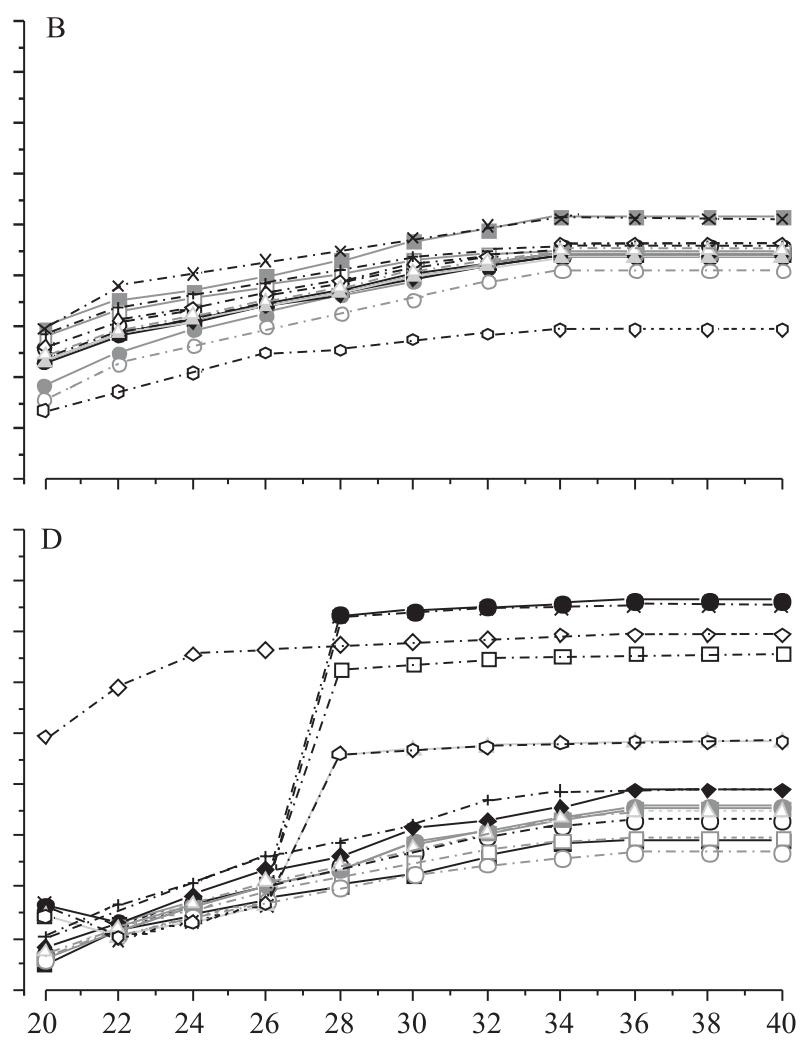

Air Temperature $\left({ }^{\circ} \mathrm{C}\right)$

\begin{tabular}{|c|c|c|c|}
\hline $\begin{array}{l}\square-\text { Cascata } 587 \\
\cdots \square \text {. Conserva } 693 \\
\cdots * \text { Oro Azteca }\end{array}$ & $\begin{array}{l}\cdots \square \cdot-\text { Cascata } 797 \\
-\quad \text { CP } 951 \mathrm{C} \\
\ldots+\cdots \text { Precocinho }\end{array}$ & $\begin{array}{l}- \text { Cascata } 848 \\
- \text { CP 9553 CYN } \\
\text { Sunblaze }\end{array}$ & 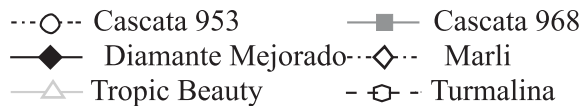 \\
\hline
\end{tabular}

Figure 2. Maximum basal temperatures (TB) determined by the method of the lowest standard deviation for peach and nectarine cultivars, between pruning-sprouting (A), sprouting-flowering (B), flowering-fruiting (C) and ripening (D) in Botucatu, SP, Brazil, between July 2006 and November 2009. 
80 hours $\left(<7^{\circ} \mathrm{C}\right)$ or 600 and 800 hours $\left(<13^{\circ} \mathrm{C}\right)$, especially in areas near Campinas, Tietê, Botucatu and Bauru, all in São Paulo. However, in Capão Bonito, SP, these authors found $\mathrm{FFD}$ and $\mathrm{NCH}$ requirements below $7.2^{\circ} \mathrm{C}$ for peach and $13^{\circ} \mathrm{C}$ for nectarine. The peach accessions 'IAC 2485-6', 'IAC 860-13' and 'Régis', and the nectarine accession 'IAC N 785-9' showed FFD, before July $10^{\text {th }}$, with $\mathrm{NCH}$ smaller than 40 and 500 , below 7.2 and $13^{\circ} \mathrm{C}$, respectively. The peach cultivars Eldorado, Diamante, Arlequim, Bolão and Marli showed FFD, after August $1^{\text {st }}$, requiring more than 70 and $650 \mathrm{NCH}$ below 7.2 and $13^{\circ} \mathrm{C}$, respectively (Pedro Júnior et al., 2007). The main peach cultivars from São Paulo, such as Aurora 1, Dourado1 and Douradão flowered between July 11 and 20, with $\mathrm{NCH}$ ranging from 41 to 50 below $7.2^{\circ} \mathrm{C}$, and from 501 to 560 below $13^{\circ} \mathrm{C}$ (Scarpare Filho et al., 2003).

Nienow \& Floss (2002) evaluated the influence of climatic conditions on the flowering of peach and nectarine, in the Central Plateau of Rio Grande do Sul state, Brazil. They concluded that the decreased frequency of low temperatures, from late June and July, resulted in earlier flowering of up to 15 days, and observed that for most cultivars and selections flowering began in July and early August.

The thermal sum requirements between pruning and harvest evidenced the three studied cultivar groups: early, semi-early and late (Table 1). 'Precocinho' required 215.9 (pruning-flowering) and 443.4 DD (fruiting-harvest), completing the total cycle with less 761 DD in comparison to 'Oro Azteca', which had the highest requirement (1,881.4 DD). The 'Cascata' group has thermal sum requirements ranging from 1,600 to $1,768 \mathrm{DD}$, except for 'Cascata 953', which was considered semi-early $(1,455.7 \mathrm{DD}$, between pruning and ripening).

The present study results corroborate the ones reported by the above authors, according to which spontaneous flowering occurred in the second half of July and in the first half of August. Flowering period and duration are influenced by a series of factors including cultural practices, varieties and climate, varying according to the region. Simão (1998) stated that flowering occurs only once, from June to August, over a short period which ranges from seven to twenty days. All cultivars flower almost simultaneously, and early or late flowering ranging from seven to fifteen days can be observed.

The studied cultivars and selections varied for duration of phenological phases, and Turmalina, Cascata 968, Cascata 848, Cascata 797, Cascata 953, Conserva 693, CP 9553 CYN and Marli had the earliest spontaneous flowering. The cultivars also showed variation among the flowering-fruiting, fruiting-harvest and harvest phenophases. The longest

Table 1. Phenophase duration (days) and thermal sum (degree days) at different phenological phases of peach and nectarine cultivars, in Botucatu, SP, Brazil.

\begin{tabular}{|c|c|c|c|c|c|c|c|c|c|c|}
\hline \multirow[t]{2}{*}{ Cultivar } & \multicolumn{2}{|c|}{ Pruning-flowering } & \multicolumn{2}{|c|}{ Flowering-fruiting } & \multicolumn{2}{|c|}{ Fruiting-harvest } & \multicolumn{2}{|c|}{ Ripening-harvest } & \multicolumn{2}{|c|}{ Cycle } \\
\hline & Thermal sum & Duration & Thermal sum & Duration & Thermal sum & Duration & Thermal sum & Duration & Thermal sum & Duration \\
\hline Oro Azteca & $230.6 \mathrm{a}$ & $16.75 \mathrm{a}$ & $558.2 \mathrm{a}$ & $44.8 \mathrm{a}$ & $795.4 \mathrm{c}$ & $73.5 \mathrm{a}$ & $297.3 \mathrm{~b}$ & $32.0 \mathrm{c}$ & $1,881.4 \mathrm{a}$ & $245.3 \mathrm{a}$ \\
\hline Turmalina & $203.2 \mathrm{a}$ & $13.5 b$ & $226.1 d$ & $22.0 \mathrm{~d}$ & $1017.6 \mathrm{a}$ & $85.8 \mathrm{a}$ & $350.2 b$ & $29.0 \mathrm{c}$ & $1,837.2 \mathrm{a}$ & $199.3 b$ \\
\hline Cascata 968 & $189.9 \mathrm{a}$ & $14.0 \mathrm{~b}$ & $456.3 b$ & $31.8 \mathrm{c}$ & $943.2 \mathrm{a}$ & $75.5 \mathrm{a}$ & $178.3 \mathrm{c}$ & $16.0 \mathrm{e}$ & $1,767.8 \mathrm{a}$ & $197.0 \mathrm{~b}$ \\
\hline Cascata 797 & $203.2 \mathrm{a}$ & $14.8 \mathrm{~b}$ & $388.7 \mathrm{c}$ & $32.0 \mathrm{c}$ & $718.4 \mathrm{c}$ & $59.3 b$ & $447.3 \mathrm{a}$ & $40.0 \mathrm{a}$ & $1,757.6 \mathrm{a}$ & $207.5 b$ \\
\hline Cascata 848 & $189.9 \mathrm{a}$ & $13.8 \mathrm{~b}$ & $434.9 \mathrm{~b}$ & $36.5 b$ & $759.5 c$ & $61.8 \mathrm{~b}$ & $356.0 \mathrm{~b}$ & $30.0 \mathrm{c}$ & $1,740.3 \mathrm{a}$ & $206.0 \mathrm{~b}$ \\
\hline CP $951 \mathrm{C}$ & $244.3 \mathrm{a}$ & $18.0 \mathrm{a}$ & $467.5 b$ & $37.8 \mathrm{~b}$ & $859.8 b$ & $67.8 \mathrm{a}$ & $167.7 \mathrm{c}$ & $15.0 \mathrm{e}$ & $1,739.2 \mathrm{a}$ & $212.3 b$ \\
\hline Diamante Mejorado & $215.9 \mathrm{a}$ & $16.3 \mathrm{a}$ & $439.0 \mathrm{~b}$ & $35.8 b$ & $887.8 b$ & $70.8 \mathrm{a}$ & $191.8 \mathrm{c}$ & $16.0 \mathrm{e}$ & $1,734.4 \mathrm{a}$ & $207.0 \mathrm{~b}$ \\
\hline Cascata 587 & $230.9 a$ & $16.5 \mathrm{a}$ & $388.0 \mathrm{c}$ & $29.5 \mathrm{c}$ & $780.2 \mathrm{c}$ & $63.8 \mathrm{~b}$ & $201.7 \mathrm{c}$ & $17.0 \mathrm{e}$ & $1,600.7 \mathrm{a}$ & $189.3 \mathrm{c}$ \\
\hline CP $9553 \mathrm{CYN}$ & $203.2 \mathrm{a}$ & $14.5 b$ & $283.0 \mathrm{~d}$ & $22.5 \mathrm{~d}$ & $888.3 b$ & $56.5 b$ & $156.3 \mathrm{c}$ & $14.0 \mathrm{e}$ & $1,530.8 b$ & $159.0 \mathrm{~d}$ \\
\hline Conserva 693 & $203.2 \mathrm{a}$ & $14.5 b$ & $239.2 \mathrm{e}$ & $19.5 \mathrm{~d}$ & $669.9 \mathrm{c}$ & $58.0 \mathrm{~b}$ & $405.9 a$ & $36.0 \mathrm{~b}$ & $1,518.2 b$ & $176.5 \mathrm{c}$ \\
\hline Marli & $203.2 \mathrm{a}$ & $15.0 \mathrm{~b}$ & $296.4 d$ & $23.5 \mathrm{~d}$ & $782.1 \mathrm{c}$ & $66.3 \mathrm{a}$ & $228.7 \mathrm{c}$ & $20.0 \mathrm{~d}$ & $1,510.4 \mathrm{~b}$ & $178.3 \mathrm{c}$ \\
\hline Cascata 953 & $201.0 \mathrm{a}$ & $14.5 b$ & $308.9 d$ & $24.8 \mathrm{~d}$ & $732.3 \mathrm{c}$ & $61.8 \mathrm{~b}$ & $213.5 \mathrm{c}$ & $19.0 \mathrm{~d}$ & $1,455.7 \mathrm{~b}$ & $173.8 \mathrm{c}$ \\
\hline Tropic Beauty & $168.2 \mathrm{a}$ & $16.0 \mathrm{a}$ & $366.9 \mathrm{c}$ & $29.5 \mathrm{c}$ & $703.2 \mathrm{c}$ & $57.8 b$ & $168.4 \mathrm{c}$ & $15.0 \mathrm{e}$ & $1,406.6 b$ & $179.8 \mathrm{c}$ \\
\hline Sunblaze (nectarine) & $203.2 \mathrm{a}$ & $15.0 \mathrm{~b}$ & $420.6 b$ & $34.8 \mathrm{~b}$ & $623.9 \mathrm{c}$ & $51.3 \mathrm{~b}$ & $123.6 \mathrm{c}$ & $10.0 \mathrm{f}$ & $1,371.3 b$ & $175.8 \mathrm{c}$ \\
\hline Precocinho & $215.9 \mathrm{a}$ & $15.8 \mathrm{a}$ & $203.2 \mathrm{e}$ & $18.8 \mathrm{~d}$ & $443.4 d$ & $38.8 \mathrm{c}$ & $257.8 \mathrm{c}$ & $21.0 \mathrm{~d}$ & $1,120.3 \mathrm{c}$ & $144.5 \mathrm{~d}$ \\
\hline $\mathrm{CV}(\%)$ & 14.91 & 11.09 & 10.71 & 12.85 & 10.05 & 14.79 & 21.78 & 8.30 & 6.71 & 7.22 \\
\hline $\mathrm{F}$ & 1.46 & 2.21 & 25.20 & 15.98 & 12.97 & 5.61 & 13.30 & 98.57 & 15.03 & 12.85 \\
\hline
\end{tabular}


harvest time was observed for 'Cascata 797' (40 days), followed by 'Conserva 693' (36 days) (Table 1). According to Simão (1998), the harvest time of a variety rarely exceeds 30 days and, if only one cultivar is grown, problems concerning labor and market will increase. Harvest time is set according to the cultivar. Ultra-early cultivars are harvested in August, very early cultivars between September and October, early cultivars in October, median cultivars from November to December, late cultivars from December to January, and very late cultivars from January to February.

Barbosa et al. (2010) evaluated several genotypes (Talismã, Néctar, Cristal, Canário, Jóia 1 and 2, Centenário, Petisco 2, Dourado 1, Natal, Delicioso Precoce, Jóia 4, Aurora 1, Tutu, Catita, Jóia 3, Colibri, Brasão, Dourado 2, Jóia 5, Supermel, Ouromel 2, Petisco, Arlequim, Régis, Real, Biuti, Tropical 1 and 2, Aurora 2, Doçura 2, Bolão, Momo and Douradão), in order to select cultivars requiring 0-200 NCH, for subtropical regions, and concluded that the productive period of these materials extended from August to February, between 80 to 180 days after full flowering.

Adopting pruning date at the end of the harvest, as the criterion for productive cycle evaluation, the productive period increases by around 15 to 60 days. Thus, in the present study, the earliest cultivars and selections were Precocinho (114.5 days) and CP 9553 CYN (159 days). Median cultivars and selections were Cascata 953 (173.8 days), nectarine Sunblaze (175.8 days), Conserva 693 (176.5 days), Marli (178.3 days), Tropic Beauty (179.8 days) and Cascata 587 (189.3 days). Later cultivars and selections were Cascata 968 (197 days), Turmalina (199.3 days), Cascata 848 (206 days), Cascata 797 (207.5 days), Diamante Mejorado (207 days) and CP $951 \mathrm{C}$ (212.3 days). The latest cultivar was Oro Azteca (245.3 days) (Table 1).

The cultivation of earlier cultivars and selections are of greater interest in subtropical regions of SP, since their fruit are harvested earlier, in comparison to those of traditional producing regions located in the South of Brazil. The production in SP begins in mid-August with early cultivars and is especially devoted to the market of fresh fruit; such production has as its main characteristic the production precocity, in comparison to the main Brazilian producing regions and also to most countries of the Southern
Hemisphere such as Chile, Argentina, Uruguay and South Africa (Pereira et al., 2002; Scarpare Filho et al., 2003).

Cultivars adapted to subtropical regions do not require long chilling hours and sprout easily, whereas cultivars more demanding as for $\mathrm{NCH}$ hardly sprout after the winter in regions of mild winter, such as SP, because they cannot accumulate sufficient $\mathrm{NCH}$ to break dormancy (Barbosa et al., 2003). In the present study, all the evaluated cultivars and selections had spontaneous flowering, although only yield was quantified (Table 2). The peach cultivars Turmalina, Marli e Tropic Beauty and the nectarine cultivar Sunblaze have great potential for cultivation in the region of Botucatu, SP, with yield exceeding $3,900 \mathrm{~kg} \mathrm{ha}^{-1}$, and 'Precocinho' can be used to increase seasonal variation in the harvest.

As regards yield, cultivars showed variations according to the evaluation year. The most productive cultivars were: Turmalina, in 2006; Turmalina, Cascata 848, Cascata 797, Conserva 693, Oro Azteca, CP 951-C and Marli, in 2007; Turmalina, Marli, Tropic Beauty and Sunblaze (nectarine), in 2008; Turmalina, Marli, Tropic Beauty and Sunblaze (nectarine), in 2009. The most promising peach cultivars were Turmalina and Marli, and the yield of Sunblaze (nectarine) was comparable to that of peach in 2008 and 2009.

Table 2. Yield $\left(\mathrm{kg} \mathrm{ha}^{-1}\right)$ of peach and nectarine cultivars in Botucatu, SP, Brazil ${ }^{(1)}$.

\begin{tabular}{lrrrc}
\hline Cultivar & 2006 & \multicolumn{1}{c}{2007} & 2008 & 2009 \\
\hline Turmalina & $3,718.7 \mathrm{Aa}$ & $2,767.3 \mathrm{Ab}$ & $4,261.7 \mathrm{Aa}$ & $3,945.0 \mathrm{Aa}$ \\
Cascata 968 & $1,037.4 \mathrm{Ca}$ & $994.4 \mathrm{Ba}$ & $1,345.9 \mathrm{Da}$ & $1,074.0 \mathrm{Da}$ \\
Cascata 848 & $2,126.6 \mathrm{Bb}$ & $2,404.0 \mathrm{Ab}$ & $3,104.6 \mathrm{Ba}$ & $3,466.3 \mathrm{Ba}$ \\
Cascata 587 & $1,097.0 \mathrm{Cb}$ & $1,614.4 \mathrm{Bb}$ & $2,486.7 \mathrm{Ca}$ & $2,430.0 \mathrm{Ca}$ \\
Cascata 797 & $1,937.0 \mathrm{Bb}$ & $2,500.0 \mathrm{Aa}$ & $2,865.7 \mathrm{Ba}$ & $2,708.3 \mathrm{Ca}$ \\
Cascata 953 & $1,527.0 \mathrm{Cb}$ & $1,656.0 \mathrm{Bb}$ & $2,023.3 \mathrm{Ca}$ & $2,359.3 \mathrm{Ca}$ \\
Conserva 693 & $2,043.1 \mathrm{Bb}$ & $2,362.9 \mathrm{Ab}$ & $2,979.0 \mathrm{Ba}$ & $3,136.7 \mathrm{Ba}$ \\
Precocinho & $1,183.4 \mathrm{Cb}$ & $1,499.7 \mathrm{Bb}$ & $2,117.3 \mathrm{Ca}$ & $2,252.3 \mathrm{Ca}$ \\
Diamante Mejorado & $1,002.4 \mathrm{Cb}$ & $1,185.2 \mathrm{Bb}$ & $2,953.3 \mathrm{Ba}$ & $2,417.3 \mathrm{Ca}$ \\
Oro Azteca & $1,181.1 \mathrm{Cc}$ & $2,242.8 \mathrm{Aa}$ & $1,776.7 \mathrm{Db}$ & $2,559.7 \mathrm{Ca}$ \\
CP 9553 CYN & $1,159.2 \mathrm{Ca}$ & $1,413.3 \mathrm{Ba}$ & $1,304.4 \mathrm{Da}$ & $1,059.0 \mathrm{Da}$ \\
CP 951 C & $1,963.0 \mathrm{Bb}$ & $2,371.7 \mathrm{Ab}$ & $3,282.3 \mathrm{Ba}$ & $3,193.3 \mathrm{Ba}$ \\
Marli & $2,267.7 \mathrm{Bb}$ & $2,822.3 \mathrm{Ab}$ & $3,714.3 \mathrm{Aa}$ & $3,969.3 \mathrm{Aa}$ \\
Tropic Beauty & $996.8 \mathrm{Cb}$ & $1,191.6 \mathrm{Bb}$ & $3,736.9 \mathrm{Aa}$ & $3,954.3 \mathrm{Aa}$ \\
Sunblaze (nectarine) & $1,209.8 \mathrm{Cb}$ & $1,361.6 \mathrm{Bb}$ & $4,001.5 \mathrm{Aa}$ & $3,832.3 \mathrm{Aa}$ \\
\hline
\end{tabular}

${ }^{(1)}$ Means followed by the same letters, upper case in the lines, and lower case in the columns, do not differ by Scott-Knott test, at 5\% probability. 


\section{Conclusions}

1. The basal minimum temperatures vary between plant phenological stages, with little difference among nectarine and peach cultivars.

2. The thermal sum required between pruning and harvesting of peach and nectarine varies between $1,455.7$ to $1,881.4$ degree-days and serves as a basis for planning the crop, with total cycle time between 144 and 245 days.

3. Some cultivars and selections are more adapted to the local climatic conditions, with great variation as to thermal requirements and their phenological phases.

\section{References}

ARNOLD, C.Y. Determination and significance of base temperature in a linear heat unit system. Proceedings of the American Society for Horticultural Science, v.74, p.430-445, 1959.

BARBOSA, W.; CHAGAS, E.A.; POMMER, C.V.; PIO, R. Advances in low-chilling peach breeding at Instituto Agronômico, São Paulo State, Brazil. Acta Horticulturae, v.872, p.147-150, 2010.

BARBOSA, W.; OJIMA, M.; DALL'ORTTO, F.A.C.; MARTINS, F.P.; CASTRO, J.L. de; SANTOS, R.R. dos. Avaliação de pessegueiros e nectarineiras introduzidos no Brasil, procedentes da Flórida, EUA. Scientia Agricola, v.54, p.152-159, 1997.

BARBOSA, W.; POMMER, C.V.; RIBEIRO, M.D.; VEIGA, R.F. de A.; COSTA, A.A. Distribuição geográfica e diversidade varietal de frutíferas e nozes de clima temperado no Estado de São Paulo. Revista Brasileira de Fruticultura, v.25, p.341-344, 2003.

CARAMORI, P.H.; CAVIGLIONE, J.H.; WREGE, M.S.; HERTER, F.G.; HAUAGGE, R.; GONÇALVES, S.L.; CITADIN, I.; RICCE, W. da S. Zoneamento agroclimático para o pessegueiro e a nectarineira no Estado do Paraná. Revista Brasileira de Fruticultura, v.30, p.1040-1044, 2008.

CITADIN, I.; RASEIRA, M. do C.B.; HERTER, F.G.; SILVA, J.B. da. Heat requirement for blooming and leafing in peach. HortScience, v.36, p.305-307, 2001.

CITADIN, I.; RASEIRA, M. do C.B.; QUEZADA, A.C.; SILVA, J.B. da. Herdabilidade da necessidade de calor para a antese e brotação em pessegueiro. Revista Brasileira de Fruticultura, v.25, p.119-123, 2003.

CLIMA dos municípios paulistas. Campinas: Centro de Pesquisas Meteorológicas e Climáticas Aplicadas à Agricultura. Disponível em: <www.cpa.unicamp.br>. Acesso em: 30 ago. 2010.

DAY, K.; LOPEZ, G.; DEJONG, T. Using growing degree hours accumulated thirty days after bloom to predict peach and nectarine harvest date. Acta Horticulturae, v.803, p.163-166, 2008.

GAO, D.S.; LI, X.L.; SHU, H.R. Effects of chemical defoliation on the end dormancy of peach trees. Journal of Fruit Science, v.19, p.269-271, 2002.
GARIGLIO, N.F.; MENDOW, M.; WEBER, M.E.; FAVARO, M.A.; GONZÁlEZ-ROSSIA, E.; PILATTI, R.A. Phenology and reproductive traits of peaches and nectarines in Central-East Argentina. Scientia Agricola, v.66, p.757-763, 2009.

LITSCHMANN, T.; OUKROPEC, I.; KIRZAN, B. Predicting individual phenological phases in peaches using meteorological data. Horticultural Science, v.35, p.65-71, 2008.

LOPEZ, G.; DEJONG, T.M. Spring temperatures have a major effect on early stages of peach fruit growth. Journal of Horticultural Science and Biotechnology, v.82, p.507-512, 2007.

MARRA, F.P.; INGLESE, P.; DEJONG, T.M.; JOHNSON, R.S. Thermal time requirement and harvest time forecast for peach cultivars with different fruit development periods. Acta Horticulturae, v.592, p.523-529, 2002.

MILATOVIC, D.; NIKOLIC, D.; DUROVIC, D. Variability, heritability and correlations of some factors affecting productivity in peach. Horticultural Science, v.37, p.79-87, 2010.

NIENOW, A.A.; FLOSS, L.W. Floração de pessegueiros e nectarineiras no Planalto Médio do Rio Grande do Sul, influenciada pelas condições meteorológicas. Ciência Rural, v.32, p.931-936, 2002.

OMETTO, J.C. Bioclimatologia vegetal. São Paulo: Agronômica Ceres, 1981. 425p.

PEDRO JÚNIOR, M.J.; BARBOSA, W.; ROLIM, G. de S.; CASTRO, J.L. de. Época de florescimento e horas de frio para pessegueiros e nectarineiras. Revista Brasileira de Fruticultura, v.29, p.425-430, 2007.

PEREIRA, F.M.; NATCHIGAL, J.C.; ROBERTO, S.R. Tecnologia para a cultura do pessegueiro em regiões subtropicais. Jaboticabal: FUNEP, 2002. 62p.

PÉREZ-PASTOR, A.; RUIZ-SÁNCHES, M.C.; DOMINGO, R.; TORRECILLAS, A. Growth and phenological stages of 'Búlida' apricot trees in south-east Spain. Agronomie, v.24, p.93-100, 2004.

RAMOS, D.P.; LEONEL, S. Características dos frutos de cultivares de pessegueiros e de nectarineira, com potencial de cultivo em Botucatu, SP. Bioscience Journal, v.24, p.10-18, 2008.

RASEIRA, M.C.B.; NAKASU, B.H. Pessegueiro. In: BRUCKNER, C.H. Melhoramento de fruteiras de clima temperado. Viçosa: UFV, 2002. p.89-126.

SACRAMENTO, C.K.; PEREIRA, F.M. Fenologia da floração da nogueira macadâmia (Macadamia integrifolia Maiden \& Betche) nas condições climáticas de Jaboticabal, São Paulo, Brasil. Revista Brasileira de Fruticultura, v.25, p.19-22, 2003.

SANTOS, H.G. dos; JACOMINE, P.K.T.; ANJOS, L.H.C. dos; OLIVEIRA, V.A. de; OLIVEIRA, J.B. de; COELHO, M.R.; LUMBRERAS, J.F.; CUNHA, T.J.F. (Ed.). Sistema brasileiro de classificação de solos. 2.ed. Rio de Janeiro: Embrapa Solos, 2006. $306 \mathrm{p}$.

SCARPARE FILHO, J.A.; KLUGE, R.A.; TAVARES, S. A cultura do pessegueiro: recomendações para o cultivo em regiões subtropicais. Piracicaba: ESALQ, 2003. 48p. 
SIMÃO, S. O pessegueiro. In: SIMÃO, S. Tratado de fruticultura. Piracicaba: FEALQ, 1998. p.651-679.

SIMONETTO, P.R.; FIORAVANÇO, J.C.; GRELLMANN, E.O. Avaliação de algumas características fenológicas e produtivas de dez cultivares e uma seleção de pessegueiro em Veranopólis, RS. Revista Brasileira de Agrociência, v.10, p.427-431, 2004.

SOIL SURVEY STAFF. Keys to soil taxonomy. $11^{\text {th }}$ ed. Washington: USDA, 2010.
SOUZA, A.P. de; RAMOS, C.M.C.; LIMA, A.D. de; FLORENTINO, H.O.; ESCOBEDO, J.F. Comparison of methodologies for degree-day estimation using numerical methods. Acta Scientiarum. Agronomy, v.33, p.391-400, 2011.

SOUZA, A.P. de; SILVA, A.C. da; LEONEL, S.; ESCOBEDO, J.F. Temperaturas basais e soma térmica para a figueira podada em diferentes épocas. Revista Brasileira de Fruticultura, v.31, p.314-322, 2009.

Recebido em 3 de agosto de 2011 e aprovado em 11 de novembro de 2011 